\title{
Organochlorine in the serum of inhabitants living near an electrochemical factory
}

\author{
Maria Sala, Jordi Sunyer, Raquel Otero, Mary Santiago-Silva, Carles Camps, Joan Grimalt
}

\begin{abstract}
Objectives-To measure the impact of occupational and lifestyle factors on concentrations of organochlorine compounds in a general population sample living near an electrochemical factory with a high airborne concentration of hexachlorobenzene (HCB).
\end{abstract}

Methods-Serum samples from 608 people (328 selected from a random sample) were collected in 1994. Information on lifestyles, occupation, and medical condition was obtained by questionnaire.

Results-HCB and polychlorinated biphenyls (PCBs) were detected in all samples (means $36.7 \mathrm{ng} / \mathrm{ml}$ and $4.3 \mathrm{ng} / \mathrm{ml}$ respectively), followed by dichlorodiphenyl dichloroethane (DDE) and $\beta$-hexachlorocyclohexane $(\boldsymbol{\beta}-\mathrm{HCH})$, found in $98.7 \%$ and $87.3 \%$ of the samples respectively (means $4.6 \mathrm{ng} / \mathrm{ml}$ and $2.5 \mathrm{ng} / \mathrm{ml}$, respectively). Concentrations of $\mathrm{HCB}$ were the highest ever reported. Occupation in the factory was the main determinant of the variation in concentrations of HCB (regression coefficients 1.52 (SEM 0.14 ) in $\ln$ (HCB) for workers in the production department, and $2.13(0.23)$ for workers in maintenance department) and explained the highest concentrations of HCB found in men of middle age. In retired workers, concentrations of $\mathrm{HCB}$ declined with time since retirement. The PCBs, dichlorodiphenyl trichloroethane (DDT), and $\beta-H C H$ were independent of the occupation and concentrations were similar to those found in other populations. Concentrations of $\beta-\mathrm{HCH}$ and DDE in the whole population, and HCB among non-workers, were higher in women than in men. Concentrations of all measured organochlorine compounds increased with age and body mass index. Consumption of locally caught fish was an independent determinant of $\mathrm{HCB}$ and PCB concentrations.

Conclusions-This population incorporated HCB directly through occupation in the electrochemical factory, by airborne pollution, and consumption of locally caught fish. Concentrations of other common organochlorine compounds were not higher than expected. Environmental exposures to these compounds deserve attention due to their persistence and potential health effects.

(Occup Environ Med 1999;56:152-158)

Keywords: organochlorine compounds; environment; occupation; exposure
There is a broad range of organochlorine compounds produced by several basic chemical processes - such as the manufacture of plastics, solvents, pesticides, and other organic chemicals. The widespread distribution and environmental persistence of these compounds or their impurities has generated major concerns on their hazard for natural ecosystems and humans. The high lipophilicity and the resistance to biodegradation allow their bioaccumulation through food chains. ${ }^{12}$ These chemicals can be found in all ecosystems, including those located far away from the site of emission. ${ }^{3}$ They have also been found in human tissues throughout the world. ${ }^{4}$ Hexachlorobenzene (HCB), $\beta$-hexachlorocyclohexane $(\beta-\mathrm{HCH})$, polychlorinated biphenyls (PCBs), $p, p^{\prime}$ dichlorodiphenyl trichloroethane $\left(p, p^{\prime}-\mathrm{DDT}\right)$ and its stable metabolite $p, p^{\prime}$-dichlordiphenyl dichlorethylene $\left(p, p^{\prime}-\mathrm{DDE}\right)$ are some of the more commonly encountered organochlorine compounds. Various toxic effects in experimental animals, including carcinogenicity, ${ }^{5}$ immunotoxicity, ${ }^{4}$ and effects on the reproductive system $^{6}$ have been reported for these compounds. In humans, several epidemiological studies have reported an association between exposure to organochlorine compounds, mainly DDT and PCBs, and several health effects - such as cancer of the breast, ${ }^{7}$ brain, ${ }^{8}{ }^{9}$ pancreas, ${ }^{10}$ thyroid, and soft tissue sarcomas, ${ }^{11}$ adverse reproductive outcomes, ${ }^{12}{ }^{13}$ Parkinson's disease, ${ }^{14}$ and developmental disorders among infants. ${ }^{15}$

Complaints of odour in the population of a rural village of 5000 inhabitants in the vicinity of an organochlorine compound factory (Flix, Catalonia, Spain) led to the detection of unusually high atmospheric concentrations of $\mathrm{HCB}$. The factory is the only one in the village. It was built in 1898 and has been producing volatile chlorinated solvents over the past four decades. During some periods DDT and PCBs were manufactured but their production ended in 1971 and 1987 respectively. A preliminary study on cancer incidence in this population showed this to be higher than that expected for cancer of the brain, thyroid, and soft tissue sarcoma among men. ${ }^{16}$ We report here the descriptive analysis of organochlorine compounds in the serum samples of inhabitants of Flix and the assessment of the impact of occupational and lifestyle factors on these concentrations.

Material and methods

STUDY POPULATION

A cross sectional study was carried out on the 4178 inhabitants of the village aged over 14 
Table 1 Means and percentiles* $(\mathrm{ng} / \mathrm{ml})$ of organochlorine compounds detected in more than $10 \%$ of serum samples from a general population living near an electrochemical factory $(n=608)$

\begin{tabular}{|c|c|c|c|c|c|c|c|}
\hline & \multicolumn{2}{|c|}{$\begin{array}{l}\text { Detectable } \\
\text { concentrations }\end{array}$} & \multirow{2}{*}{$\begin{array}{l}\text { Mean } \\
(n g / m l)\end{array}$} & \multirow[b]{2}{*}{$\operatorname{Max}$} & \multicolumn{3}{|c|}{ Percentile } \\
\hline & $n$ & $\%$ & & & 25 & 50 & 75 \\
\hline Pentcb & 176 & 28.4 & 0.39 & 5.70 & 0.15 & 0.15 & 0.30 \\
\hline HCB & 608 & 100 & 36.7 & 1485.0 & 9.82 & 16.5 & 25.0 \\
\hline$\beta-\mathrm{HCH}$ & 541 & 87.3 & 9.2 & 234.10 & 2.8 & 6.60 & 13.80 \\
\hline PCB-28 & 115 & 18.5 & 0.31 & 2.80 & 0.10 & 0.15 & 0.30 \\
\hline OCE & 167 & 26.9 & 0.55 & 3.60 & 0.15 & 0.20 & 0.60 \\
\hline$p, p^{\prime}-\mathrm{DDE}$ & 612 & 98.7 & 9.61 & 222.90 & 2.10 & 5.20 & 12.80 \\
\hline PCB-118 & 255 & 41.1 & 0.38 & 5.80 & 0.10 & 0.20 & 0.50 \\
\hline PCB-153 & 519 & 83.7 & 1.46 & 40.90 & 0.50 & 0.90 & 1.60 \\
\hline$p, p^{\prime}-\mathrm{DDT}$ & 384 & 61.9 & 0.94 & 6.50 & 0.20 & 0.65 & 1.30 \\
\hline PCB-138 & 533 & 86.0 & 1.25 & 35.00 & 0.40 & 0.80 & 1.40 \\
\hline PCB-180 & 546 & 88.1 & 1.80 & 63.50 & 0.50 & 1.0 & 1.9 \\
\hline PCBs & 608 & 100 & 4.30 & 143.43 & 1.27 & 2.64 & 4.92 \\
\hline
\end{tabular}

All values in this table refer to samples with detectable levels from the 608 analysed. Pentcb=pentachlorobenzine

years in June 1994. Subjects from a random sample of this general population older than 14 years $(n=777)$ were asked to answer a questionnaire about residence, occupation, lifestyle, and medical history, administered by trained interviewers $(n=549,70.5 \%$ response rate) and to provide biological samples $(n=328,42.1 \%$ response rate). Also, from the rest of this general population, 1251 subjects completed the questionnaire 280 of whom also provided biological samples voluntarily. No differences were found in socioeconomic and occupational variables and chronic diseases between subjects from the random samples with and without biological samples-for example, mean age 50.1 and 47.9 years respectively. ${ }^{17}$ There were no differences in socioeconomic and occupational variables or in HCB serum concentrations between the 328 subjects of the random sample and the 280 volunteers - for example, geometric mean of $\mathrm{HCB}=16.9 \mathrm{ng} / \mathrm{ml}$ and $16.6 \mathrm{ng} / \mathrm{ml} \mathrm{respec}-$ tively. Written consent for inclusion in the study was obtained in all cases. The 608 serum samples analysed in the present study corresponded to 249 men and 359 women aged 50.2 and 47.9 years, respectively.

\section{EXPOSURE ASSESSMENT}

Organochlorine compounds in serum samples were analysed by gas chromatography (GC) coupled to electron capture detection. Selected samples were analysed by GC coupled to chemical ionisation negative ion mass spectrometry. All the analyses were carried out in the Department of Environmental Chemistry (CID-CSIC). Details on the methods have been reported elsewhere. ${ }^{18}$ Detection limits for $\mathrm{HCB}, \beta-\mathrm{HCH}, p, p^{\prime}-\mathrm{DDE}$, and PCBs were 0.2 , $1.1,0.7$, and 0.05 , respectively. Comparisons of the analytical performance of this laboratory with those of leading laboratories in The Netherlands, Monaco, and United States over real blood samples with different ranges of concentration of organochlorinated compounds-for example, HCB in the order of 2.2, 19, 44, and $95 \mathrm{ng} / \mathrm{ml}$ - showed that for the more abundant compounds, HCB and $p, p$-DDE, analytical results of this laboratory were always from $10 \%-20 \%$ below the average of the results from all participating laboratories. In the case of the concentrations of minor compounds, in the order of $1 \mathrm{ng} / \mathrm{ml}$, the results from this laboratory with respect to the whole group typically deviated by between $20 \%$ and $30 \%$.

The exposure information obtained through the questionnaire was place of birth, place of residence, years of residence in Flix, use of pesticides, usual consumption of fish from the water reservoir that receives the discharges of the electrochemical plant, and occupation in the electrochemical factory. Information on specific jobs, departments, and duration of the employment in the electrochemical factory was also obtained for current and past workers.

\section{STATISTICAL ANALYSIS}

Initial descriptive statistical variables were computed. Because the distribution of serum concentrations of organochlorine compounds was skewed to the right, natural logarithmic transformations were used in the analysis. The concentration of organochlorine compounds below the detection limit were set at half the limit of detection in the analysis of 608 biological samples. Multiple linear regression analysis was conducted to model the main factors found in association with serum concentrations of organochlorine compounds. We introduced all exposure variables and the potential confounders such as age, sex, parity, social class, alcohol consumption, smoking habits, and medication in the regression model. Criteria for excluding variables from the final model were lack of association with the dependent variable $(p>0.10)$ and lack of any confounding effect. If a variable was significant for a model of one organochlorine compound, we present the coefficients for this variable in the models for the other compounds. Analysis of residuals showed no violation of basic statistical assumptions. All statistical analyses were conducted with the SPSS package (SPSS, Chicago, IL, USA).

\section{Results}

Description of organochlorine compounds detected in more than $10 \%$ of serum samples of the village inhabitants is shown in table 1 . Detectable concentrations of HCB and PCBs were found in all samples. The most prevalent PCB congener was the number 180 . Detectable concentrations of $p, p^{\prime}-\mathrm{DDE}$, and $\beta-\mathrm{HCH}$ were found in $98.7 \%$ and $87.3 \%$ of the cases analysed respectively. The highest concentrations were found for $\mathrm{HCB}$, with a mean of 36.7 $\mathrm{ng} / \mathrm{ml}$ and a maximum of $1485 \mathrm{ng} / \mathrm{ml}$. Among the rest of the compounds, octachloroestyrene was the most common, being detectable in $27 \%$ of the serum samples. This study will be focused on the most prevalent compounds in these serum samples: $\mathrm{HCB}, \beta-\mathrm{HCH}, p, p^{\prime}-$ DDE, and PCBs (summation of congeners Nos 28, 52, 101, 118, 153, 138, and 180).

Table 2 shows the relation between HCB, $\beta-\mathrm{HCH}, \mathrm{p}, \mathrm{p}$ '-DDE, and PCBs concentrations and sample characteristics. Concentrations of $\mathrm{HCB}$ and PCBs were higher in men than in women $(p<0.01)$. Although concentrations of 
Table 2 Crude mean (SD) concentrations of organochlorine compounds in serum (ng/ml) by sex, age, weight, and some variables related to exposure

\begin{tabular}{|c|c|c|c|c|c|}
\hline & $n$ & $H C B$ & $\beta-H C H$ & $p, p^{\prime} D D E$ & $P C B s$ \\
\hline \multicolumn{6}{|l|}{ Sex: } \\
\hline Female & 359 & $17.6(14.0)^{\star \star}$ & $10.2(13.2)^{\star \star}$ & $9.9(15.6)$ & $3.1(3.0)^{\star \star}$ \\
\hline Male & 249 & $64.2(159.8)$ & $7.8(17.0)$ & $9.0(11.5)$ & $5.9(11.1)$ \\
\hline Total & 608 & 36.7 (127.7) & $9.2(14.9)$ & $9.6(14.1)$ & $4.3(7.6)$ \\
\hline \multicolumn{6}{|l|}{ Age (y): } \\
\hline$<45$ & 259 & $34.4(116.1)^{\star \star}$ & $3.1(3.8)^{\star \star}$ & $4.3(6.1)^{\star \star}$ & $2.4(2.4)^{\star \star}$ \\
\hline $45-64$ & 210 & $39.4(100.9)$ & $10.9(10.5)$ & $12.1(18.1)$ & $5.8(11.5)$ \\
\hline$>64$ & 139 & $21.2(9.7)$ & $18.2(24.1)$ & $15.7(14.4)$ & $5.6(5.6)$ \\
\hline \multicolumn{6}{|c|}{ Body mass index in quartiles $\left(\mathrm{kg} / \mathrm{m}^{2}\right)$ : } \\
\hline$<22.4$ & 151 & $31.9(144.1)^{\star \star}$ & $4.7(6.9)^{\star \star}$ & $6.9(19.8)^{\star \star}$ & $3.0(4.9)^{\star \star}$ \\
\hline $22.4-24.8$ & 152 & $50.1(170.2)$ & $6.6(7.7)$ & $8.2(11.1)$ & $3.5(4.5)$ \\
\hline $24.9-27.4$ & 152 & $38.9(92.9)$ & $12.3(21.5)$ & $11.0(12.3)$ & $5.6(12.2)$ \\
\hline$>27.4$ & 151 & $38.8(84.7)$ & $13.4(16.6)$ & $12.2(10.7)$ & $5.1(5.8)$ \\
\hline \multicolumn{6}{|l|}{ Loss of weight: } \\
\hline No & 555 & $39.4(126.6)$ & $9.1(15.23)$ & $9.6(14.3)$ & $4.2(7.8)$ \\
\hline Yes & 49 & $47.1(145.1)$ & $10.9(12.0)$ & $9.6(11.0)$ & $4.5(4.2)$ \\
\hline \multicolumn{6}{|c|}{ Duration of residence in Flix (y): } \\
\hline $0-9$ & 29 & $38.5(140.9)^{\star \star}$ & $6.2(6.7)^{\star \star}$ & $7.0(6.9)^{\star \star}$ & $2.2(2.7)^{\star \star}$ \\
\hline $10-19$ & 67 & $42.2(189.1)$ & $3.2(5.3)$ & $4.0(7.1)$ & $1.3(1.4)$ \\
\hline$>19$ & 511 & $39.6(116.9)$ & $10.2(15.9)$ & $10.4(14.9)$ & $4.8(8.1)$ \\
\hline \multicolumn{6}{|c|}{ Distance from residence to factory: } \\
\hline Far & 109 & $550(198.7)$ & $11.3(27.1)$ & $9.7(13.4)$ & $3.9(4.0)$ \\
\hline Medium & 277 & $32.1(82.8)$ & $9.9(11.7)$ & $10.2(16.5)$ & $4.9(10.2)$ \\
\hline Close & 174 & $40.8(132.6)$ & $7.2(8.6)$ & $8.2(10.3)$ & $3.7(4.3)$ \\
\hline Very close & 41 & $48.7(118.0)$ & $8.1(10.1)$ & $11.2(12.6)$ & $3.9(4.5)$ \\
\hline \multicolumn{6}{|l|}{ Use of pesticides: } \\
\hline No & 143 & $46.0(141.9)$ & $12.4(24.3)^{\star}$ & $10.4(11.8)$ & $5.1(7.0)$ \\
\hline Yes & 89 & $83.2(232.1)$ & $7.5(7.7)$ & $9.3(10.6)$ & $7.3(15.5)$ \\
\hline Unknown & 376 & $27.3(74.2)$ & $8.4(10.8)$ & $9.3(15.6)$ & $3.3(3.8)$ \\
\hline \multicolumn{6}{|c|}{ Local fish consumption: } \\
\hline No & 591 & $35.0(123.9)^{\star}$ & $9.2(15.06)$ & $9.5(14.1)$ & $4.1(7.5)^{\star \star}$ \\
\hline Yes & 17 & $95.3(203.3)$ & $10.4(11.2)$ & $10.5(13.7)$ & $7.9(8.6)$ \\
\hline \multicolumn{6}{|c|}{ Occupation in the electrochemical factory: } \\
\hline Never & 421 & $16.8(17.1)^{\star \star}$ & $8.7(11.9)$ & $9.1(14.7)$ & $3.2(3.1)$ \\
\hline Past workers & 130 & $63.6(154.0)$ & $13.1(23.5)$ & $12.5(14.1)$ & $8.2(14.7)$ \\
\hline Current workers & 57 & $120.2(224.0)$ & $4.3(5.5)$ & $6.3(7.0)$ & $3.3(2.8)$ \\
\hline Administration & 3 & $15.7(7.1)$ & $5.3(5.2)$ & $5.9(4.1)$ & $2.1(0.6)$ \\
\hline Laboratory & 6 & $48.6(71.9)$ & $6.6(8.5)$ & $4.3(2.6)$ & $2.9(3.1)$ \\
\hline Production & 36 & $105.4(151.5)$ & $4.1(5.3)$ & $7.2(8.2)$ & $3.5(2.5)$ \\
\hline Maintenance & 12 & $247.1(410.2)$ & $3.4(4.3)$ & $5.3(3.9)$ & $4.0(4.6)$ \\
\hline \multicolumn{6}{|c|}{ Duration of employment (y): } \\
\hline$<5$ & 7 & $259.9(244.6)$ & $2.1(2.5)$ & $4.3(4.1)^{\star}$ & $2.6(4.1)$ \\
\hline $5-9$ & 21 & $184.9(322.3)$ & $2.4(3.9)$ & $4.1(4.8)$ & $3.1(1.9)$ \\
\hline $10-19$ & 15 & $42.5(41.2)$ & $5.2(6.6)$ & $8.3(9.4)$ & $3.3(2.3)$ \\
\hline$>19$ & 16 & $60.4(106.2)$ & $6.7(6.1)$ & $8.7(7.0)$ & $4.5(4.1)$ \\
\hline
\end{tabular}

${ }^{\star} \mathrm{p}<0.05 ;{ }^{\star} \mathrm{p}<0.01$. Comparisons between the categories of a variable with ANOVA. All statistical tests involved logarithmic transformation of the dependent variable.

$\beta-\mathrm{HCH}$ and $p, p$-DDE increased slightly by age, concentrations of $\mathrm{HCB}$ and to a lesser extent PCBs decreased in the oldest age group. All four compounds increased with body mass index $\left(\mathrm{kg} / \mathrm{m}^{2}\right)$ and with years of residence in Flix. However, distance of residence from the factory did not show any association with serum concentrations of organochlorine. Those who consumed fish from the water reservoir of Flix had higher concentrations of HCB and PCBs than non-consumers. No significant differences related to occupation were found in the serum concentrations of organochlorine compounds other than HCB. For $\mathrm{HCB}$, the highest concentrations were found for current workers in the factory, most of them being men, and retired workers around 60 years old, whereas the lowest were found among people who had never been employed in the factory (figure 1). Among current workers, those in the maintenance and production departments had higher concentrations of HCB than those in the administrative sections. Duration of employment did not show any association with HCB concentrations. Workers with $<10$ years of employment had higher concentrations than workers with $>10$ years of employment, but differences were not significant. For $\beta-\mathrm{HCH}, p, p^{\prime}-\mathrm{DDE}$, and PCBs, concentrations increased with duration of employment, but differences disappeared after adjusting for age.

Table 3 presents the results of multiple linear regression analysis for the concentrations of $\mathrm{HCB}, \beta-\mathrm{HCH}, p, p^{\prime}-\mathrm{DDE}$, and PCBs in the whole study population. A model for HCB in non-workers is also presented as occupation in the electrochemical factory was a strong predictor of HCB concentrations. Predictors of $\beta-\mathrm{HCH}, p, p^{\prime}-\mathrm{DDE}$, and PCBs concentrations among non-workers were similar to those for the whole population. Concentrations of $\beta-\mathrm{HCH}$ and $p, p^{\prime}-\mathrm{DDE}$ in the whole population and concentrations of $\mathrm{HCB}$ in non-workers were higher in women than in men. Age and body mass index were both significantly associated with serum concentrations of all four compounds. Nevertheless, for HCB, the increase by age occurred only in women. In men, a decrease was found in those older than 64 years. An increase of HCB concentrations with age was found in both sexes when workers were excluded from the whole study population. Years of residence in Flix did not enter the model probably because of the high collinearity with age. Consumption of locally caught fish was associated with HCB and PCB concentrations. For HCB, the strongest association was 


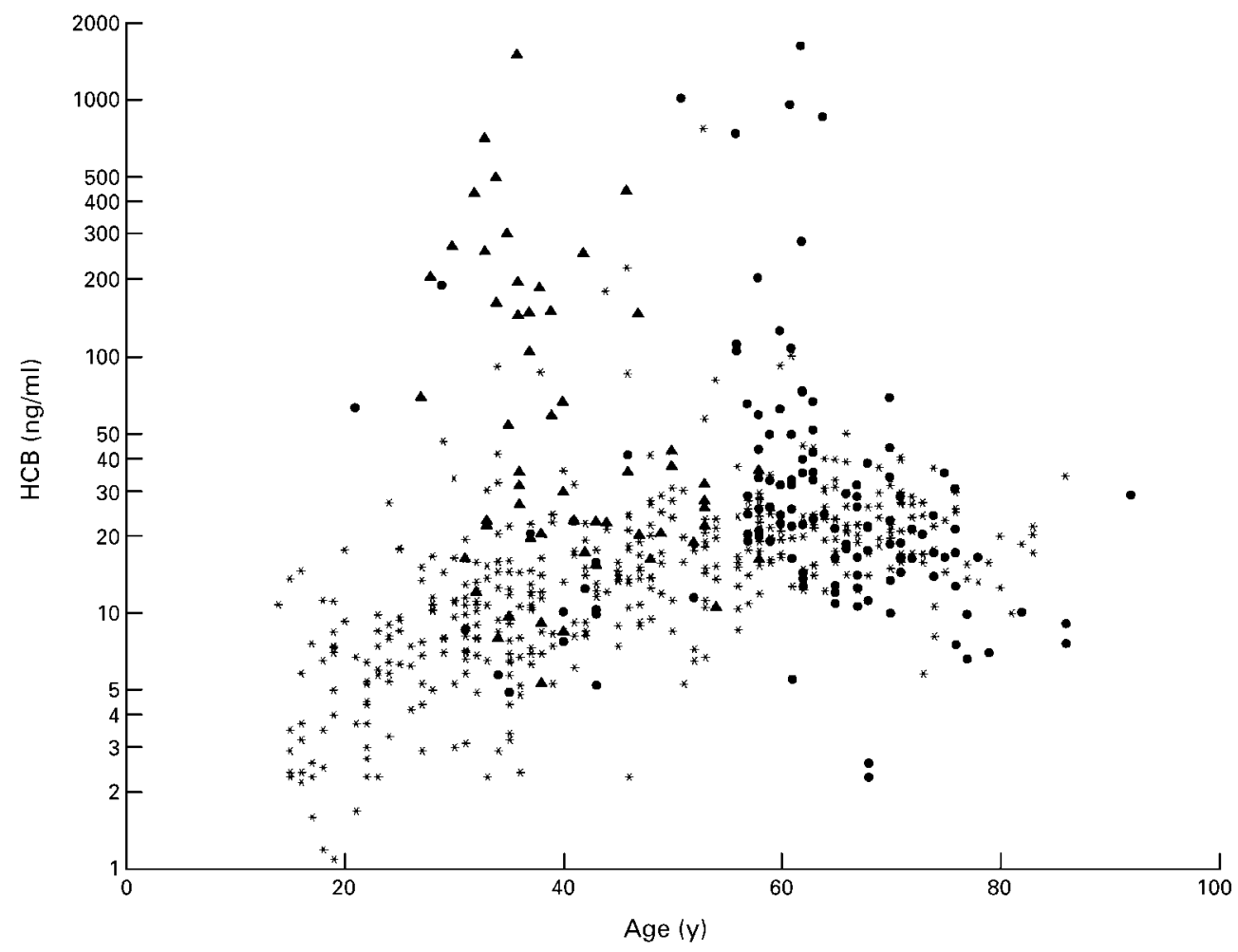

Figure 1 HCB concentrations in serum by age and occupation in the electrochemical factory. * never workers, $\mathbf{\Delta}$ current workers, • past workers.

for current occupation in the maintenance and production department of the electrochemical plant, then for retired workers. No information was available on breast feeding history among women, but the investigation of the relation between parity and concentrations of serum organochlorine, did not show any significant association ( $\mathrm{p}$ values $>0.08$ ).

Among retired workers, concentrations of $\mathrm{HCB}$ decreased with years since retirement (figure 2). The concentrations among those with $<3$ years of retirement were similar to concentrations among current workers. The concentrations became similar to those who had never worked after $\geqslant 10$ years of retirement. Age adjusted concentrations showed the same pattern. The difference between concentrations in current workers and retired workers were only significant for the group of workers with between 5 and 9 years of retirement.

Table 3 Predictorst (coefficient (SE)) of the natural logarithm of the concentration (ng/ml) of (HCB), (b-HCH), $(p, p$ 'DDE) and (PCBs) in serum of 608 inhabitants near an organochlorine compounds factory in Flix (Catalonia, Spain)

\begin{tabular}{|c|c|c|c|c|c|}
\hline Variables & $\begin{array}{l}\ln (H C B) \\
(n=608)\end{array}$ & $\begin{array}{l}\ln (H C B)(n=421) \\
\text { Non-workers }\end{array}$ & $\begin{array}{l}\ln (\beta-H C H) \\
(n=608)\end{array}$ & $\begin{array}{l}\ln \left(p, p^{\prime} D D E\right) \\
(n=608)\end{array}$ & $\begin{array}{l}\ln (P C B s) \\
(n=608)\end{array}$ \\
\hline Constant $\ddagger$ & $2.22(0.06)^{\star \star}$ & $2.61(0.03)^{\star \star}$ & $1.19(0.11)^{\star \star}$ & $1.47(0.06)^{\star \star}$ & $0.54(0.06)^{\star \star}$ \\
\hline Male & - & $-0.36(0.06)^{\star \star}$ & $-0.96(0.22)^{\star \star}$ & $-0.19(0.13)$ & $0.07(0.13)$ \\
\hline Age(y) & - & $0.02(0.001)^{\star \star}$ & $0.06(0.006)^{\star \star}$ & $0.04(0.003)^{\star \star}$ & $0.02(0.003)^{\star \star}$ \\
\hline \multicolumn{6}{|l|}{ Age and sex: } \\
\hline 45-64 Women & $0.60(0.09)^{\star \star}$ & & & & \\
\hline$>64$ Women & $0.72(0.11)^{\star \star}$ & & & & \\
\hline$<45$ Men & $-0.07(0.11)$ & & & & \\
\hline 45-64 Men & $0.50(0.13)^{\star \star}$ & & & & \\
\hline$>64 \mathrm{Men}$ & $-0.06(0.07)$ & & & & \\
\hline Body mass index $\left(\mathrm{kg} / \mathrm{m}^{2}\right)$ & $0.04(0.01)^{\star \star}$ & $0.04(0.01)^{\star \star}$ & $0.07(0.02)^{\star \star}$ & $0.05(0.013)^{\star \star}$ & $0.02(0.013) \rrbracket$ \\
\hline Weight loss & $0.20(0.11) \S$ & $0.24(0.09)^{\star \star}$ & $0.13(0.3)$ & $0.13(0.17)$ & $0.21(0.17)$ \\
\hline Fish consumption & $0.41(0.2)^{\star}$ & $0.32(0.18) \S$ & $0.24(0.5)$ & $0.30(0.3)$ & $0.76(0.29)^{\star \star}$ \\
\hline Use of pesticides & $0.07(0.1)$ & $-0.08(0.1)$ & $-0.16(0.25)$ & $-0.05(0.15)$ & $0.34(0.14)^{\star}$ \\
\hline Retired workers & $0.71(0.11)^{\star \star}$ & - & $-0.03(0.28)$ & $-0.08(0.16)$ & $0.25(0.16)$ \\
\hline \multicolumn{6}{|l|}{ Current workers: } \\
\hline Administration & $0.68(0.28)^{\star}$ & - & $0.94(0.74)$ & $0.02(0.42)$ & $-0.06(0.42)$ \\
\hline Production & $1.52(0.14)^{\star \star}$ & - & $-0.05(0.37)$ & $0.39(0.21)$ & $0.32(0.21)$ \\
\hline Maintenance & $2.13(0.23)^{\star \star}$ & - & $-0.88(0.62)$ & $0.24(0.35)$ & $0.21(0.35)$ \\
\hline Multiple $\mathrm{R}^{2}$ & 0.39 & 0.48 & 0.27 & 0.28 & 0.19 \\
\hline
\end{tabular}

${ }^{\star} \mathrm{p}<0.05 ;{ }^{\star \star} \mathrm{p}<0.01 ; \mathrm{s} \leqslant 0.08$.

†All coefficients are adjusted for the variables presented in the table. Adjustment for parity, social class, alcohol consumption, smoking habits, and medication did not change the results. These variables did not enter in the model $(p>0.2)$. The coefficient gives the ratio of the geometric mean of the concentrations of the compound considered for people exposed compared with those in the reference category.

$\ddagger$ The reference category are women $<45$ years old, without weight loss, non-consumers of fish, non-users of pesticides, and who had never worked in the electrochemical factory. 


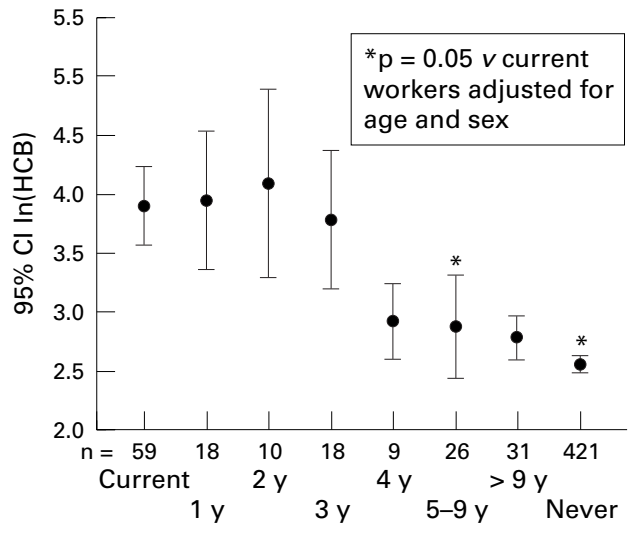

Figure 2 Means of $\ln (\mathrm{HCB})$ and $95 \%$ CI in current workers, in retired workers by years of retirement, and in never workers. ${ }^{\star} p=0.05$ v current workers, adjusted by age and sex.

\section{Discussion}

The high concentrations of HCB in this population, and their relation with occupation in the electrochemical factory, may reflect inadequacies in the working conditions of the factory. Concentrations of $\beta-\mathrm{HCH}, p, p^{\prime}-\mathrm{DDE}$, and PCBs in this study were as high as have been found in other populations without any particularly high exposure. ${ }^{79-22}$ Apart from the effect of occupation in the electrochemical factory on $\mathrm{HCB}$, age and body mass index were the main predictors of $\mathrm{HCB}, \beta-\mathrm{HCH}, p, p^{\prime}-$ DDE, and PCBs in serum.

Serum concentrations of HCB in this study are the highest ever described. Concentration of $\mathrm{HCB}$ in serum of 370 subjects from the United States general population studied by Needham et al averaged $0.19 \mathrm{ng} / \mathrm{ml} .^{23}$ In four population groups (total of 97 samples) in Zagreb (Croatia), serum concentrations of HCB ranged from $<0.5$ to $1.0 \mathrm{ng} / \mathrm{ml} .{ }^{20}$ The groups included workers employed in the distribution and packing of seeds treated with different pesticides. Analysis of blood plasma samples collected from Germany showed that median annual concentrations of HCB between 1983 and 1989 ranged from 3.1 to 5.4 $\mathrm{ng} / \mathrm{ml}^{24}$ The mean serum concentration described in a highly exposed population through the consumption of fish was $15 \mathrm{ng} / \mathrm{ml}$ in sports fishermen in the Elb river (Germany), ${ }^{25}$ which is similar to the mean of the general population of Flix who had never worked in the electrochemical factory. However, the highest concentration found in that population was 55.2 whereas in ours, in non-workers, was 222.0 $\mathrm{ng} / \mathrm{ml}$. Concentrations of $\beta-\mathrm{HCH}, p, p^{\prime}-\mathrm{DDE}$, and PCBs were in the range reported in other studies. $^{719-22}$ Results of variability between laboratories confers validity to the results of HCB presented in this study.

Although biases due to the low response rate could compromise the ability of the results of this study to be generalised, the non-participants and participants did not differ in socioeconomic variables. ${ }^{17}$ Moreover, participants did not know the specific objectives of the study nor their organochlorine concentrations and the response rate among current workers $(41.8 \%$ of total current workers) was the same as that of the total study population. Also, no differences in the results were found when analysing volunteers and subjects from the random sample separately. Overall these arguments suggest that the results were not due to a selection bias.

Pollution by HCB is generated as a by product in the synthesis of chlorinated solvents. This activity was carried out in the factory during past decades, and was the most probable source of the high airborne concentrations of HCB found repeatedly in the village. ${ }^{16}$ The high concentrations detected in serum samples of this population probably reflect the incorporation of this compound through the respiratory system. Also, concentrations of organochlorine compounds in foodstuffs produced in this village, were similar to those found in other studies, ${ }^{26}$ and represent a small fraction of the total dietary intake. Usual diet does not, therefore, explain the high concentrations of HCB in serum. Only consumption of fish from the water reservoir of Flix was associated with high concentrations of HCB and PCBs, probably reflecting the practice of dumping chemical waste into the water reservoir.

Women had higher concentrations of $\beta-\mathrm{HCH}$ and $p, p$-DDE, and among nonworkers, of women had higher concentrations of HCB than men. Other studies also reported higher concentrations in women than in men. ${ }^{27}{ }^{28}$ This difference could be related to differences in metabolism. It has been found that metabolism of HCB mediated by glutathion was higher in men than in women. ${ }^{29}$ Few studies have assessed differences in organochlorine concentrations by sex, partly because most of the studies have been done only on women. In other studies no consistent differences have been reported, ${ }^{24}{ }^{30}$ but failure to adjust for occupation may explain part of these inconsistencies.

Concentrations of organochlorine compounds increased with age. This has also been found in studies of blood samples or adipose tissue samples. ${ }^{2}{ }^{31}{ }^{32}$ In our study, an interaction between age and sex was found for HCB concentrations. The interaction was not found for non-workers, implying that it could be related to the exposure in the factory. Men in the oldest age group are retired from the factory and therefore they are no longer so highly exposed. The decline of HCB concentrations after retirement from the electrochemical factory, could reflect the half life of this compound in humans. Because of the cross sectional nature of data, serial samples from the same person are not available. Nevertheless, mean HCB concentrations were lower in retired workers with $\geqslant 3$ years of retirement, suggesting that the half life could be between 3 and 4 years. Previous information on the half life of HCB in humans is scarce. Currier et $a l^{33}$ estimated this period as 2 years based on a small study of workers who were transferred from a department with potential exposure to $\mathrm{HCB}$ to production areas free from such exposure. The half lives estimated in monkeys were 2.5-5 years. ${ }^{34}$ Duration of employment among work- 
ers was not related to organochlorine concentrations. Workers with few years of employment had the highest concentrations of HCB, suggesting that they may have been carrying out the most exposed jobs. Concentrations of $\beta-\mathrm{HCH}, p, p^{\prime}-\mathrm{DDE}$, and PCBs were higher in past workers than in current workers but this is to be expected because PCBs and DDT are no longer produced.

Relation with body mass index has also been reported. ${ }^{25}$ Changes in body weight during the weeks or months preceding sampling may also influence organochlorine concentrations. ${ }^{35}$ When lipolysis of stored fat occurs, persistent lipophilic chemicals contained in the fat are mobilised and redistributed. ${ }^{36}$ In our study, body mass index as well as loss of weight were associated with organochlorine concentrations although weight loss was only significant for HCB concentrations. People consuming fish caught in the Flix water reservoir had higher concentrations of HCB and PCBs than nonconsumers. The difference was significant although only 17 persons reported that they ate local fish. Consumption of seafood and fish has been reported to be an important source of organochlorine compounds. ${ }^{22} 253237$ Distance of residence from the factory was not related to HCB concentrations probably due to the distances being small in the area studied.

Some studies have found an association between alcohol consumption and smoking and PCBs and DDE concentrations in breast milk. ${ }^{232}$ In our study, no association was found with any of the concentrations of organochlorine compounds in serum samples. Among women, organochlorine compounds-such as PCBs and DDT in milk decreases with the number of breastfed children. ${ }^{2}$ It has been reported that organochlorine concentrations in milk decrease with parity, a surrogate for past breastfeeding. In our study, although adjusting for age, related to both parity and organochlorine compounds, no significant association was found.

In conclusion, an important impact of a point source emission on the body burden of HCB in the surrounding general population has been investigated. Occupation in the factory was the main determinant of the variation in concentrations of HCB and explained the differences in age and sex. Airborne pollution, however, explained the high concentrations of HCB compared with other organochlorine compounds among non-workers. A second minor source of organochlorine intake was local fish consumption, particularly for $\mathrm{HCB}$ and PCBs. Concentrations of $\beta-\mathrm{HCH}$, DDE, and PCBs did not vary with occupation, signalling background concentrations probably incorporated through diet. $\beta-\mathrm{HCH}, p, p^{\prime}-\mathrm{DDE}$, and HCB among non-workers, were higher among women than men, and serum concentrations of all organochlorine compounds analysed increased with age and body mass index. These aspects are important when considering body burden and effects in human populations environmentally or occupationally exposed to organochlorines. The study also provides useful information for surveillance around the world of the many populations still highly exposed to some of these compounds with potentially severe health effects.

The collaboration of the Primary Health Care Center of Flix is highly appreciated. This work was supported by a grant from the "Fondo de Investigación Sanitaria", Spain (FIS 93/0006-01).

1 Lilienfeld DE, Gallo MA. 2,4-D, 2,4,5-T, and 2,3,7,8-TDD: an overview. Epidemiol Rev 1989;11:28-58.

2 Dewailly E, Ayotte P, Laliberté C, et al. Polychlorinated biphenyl (PCB) and dichlorodiphenyl dichloroethylene (DDE) concentrations in the breast milk of women in Quebec. Am f Public Health 1996;86:1241-6.

3 Dewailly E, Ayotte P, Bruneau S, et al. Inuit exposure to organochlorines through the aquatic food chain in arctic Québec. Environ Health Perspect 1993;101:618-20.

4 Hattula ML, Ikkala J, Isomaki M, et al. Chlorinated hydrocarbon residues (PCB and DDT) in human liver, adipose tissue and brain in Finland. Acta Pharmacol et Toxicol 1976; 39:545-54.

5 Woodruff T, Wolff MS, Davis DL, et al. Organochlorine exposure estimation in the study of cancer etiology. Environ Res 1994;65:132-44.

6 Kelce WR, Stone CR, Laws SC, et al. Persistent DDT metabolite $p, p$-DDE is a potent androgen receptor antagonist. Nature 1995;375:581-5.

7 Wolff MS, Toniolo PG, Lee EW, et al. Blood levels of organochlorine residues and risk of breast cancer. $₹$ Natl Cancer Inst 1993;85:648-52.

8 Wrensch M, Bondy ML, Wiencke J, et al. Environmental risk factors for primary malignant brain tumors: a review. $\mathcal{f}$ Neurooncol 1993;17:47-64.

9 Sinks T, Steele G, Smith AB, et al. Mortality among workers exposed to polychlorinated biphenyls. Am $\mathcal{F}$ Epidemiol 1992;136:389-98

10 Garabrant DH, Held J, Langholz B, et al. DDT and related compounds and risk of pancreatic cancer. $\mathcal{F}$ Natl Cancer Inst 1992;84:764-71.

11 Saracci R, Kogevinas M, Bertazzi PA, et al. Cancer mortality in workers exposed to chlorophenoxy herbicides and chlorophenols. Lancet 1991;338:1027-32.

12 Savitz DA, Olshan AF, Gallagher K. Maternal occupation and pregnancy outcome. Epidemiology 1996;7:269-74.

13 Karmaus W, Wolf N. Reduced birthweight and length in the Karmaus W, Wolf N. Reduced birthweight and length in the
offsping of females exposed to PCDFs, PCP, and Lindane. offsping of females exposed to PCDFs, PCP,

14 Semchuk K, Love E. Effects of agricultural work and other proxy-derived case-control data on Parkinson's disease risk proxy-derived case-control data on Parkinso

15 Rogan WJ, Gladen BC. PCBs, DDE, and child development at 18 and 24 months. Ann Epidemiol 1991;1:407-13.

6 Grimalt JO, Sunyer J, Moreno V, et al. Risk excess of soft-tissue sarcoma and thyroid cancer in a community exposed to airborne organochlorinated compound mixtures with a high hexachlorobenzene content. Int $\mathcal{f}$ Cancer 1994;56:200-3

17 Sala M, Sunyer J, Otero R, et al. Health effects of chronic high exposure to hexachlorobenzene in a general population sample. Arch Environ Health 1998; (in press).

18 Otero R, Santiago-Silva M, Grimalt JO. Hexachlorobenzene in human blood serum. F Chromatogr 1997;778:87-94.

19 Jacobson JL, Humphrey HEB, Jacobson SW, et al. Determinants of polychlorinated biphenyls (PCBs), polybrominants of polychlorinated biphenyls (PCBs), polybromi-
nated biphenyls (PBBs), and dichlorodiphenyl trichloroethane (DDT) levels in the sera of young children. Am $\mathcal{F}$ roethane (DDT) levels in the sera

20 Krauthacker B. Levels of organochlorine pesticides and polychlorinated biphenyls (PCBs) in human milk and serum collected from lacting mothers in the northern Adriatic area of Yugoslavia. Bull Environ Contam Toxicol 1991;46:797-802.

21 Kocan A, Petrik J, Drobna B, et al. Levels of PCBs and some organochlorine pesticides in the human population of selected areas of the Slovak Republic. Chemosphere 1994;29:2315-25.

22 Schantz SL, Jacobson JL, Humphrey HE, et al. Determinants of polychlorinated biphenyls (PCBs) in the sera of mothers and children from Michigan farms with PCBcontaminated silos. Arch Environ Health 1994;49:452-8.

23 Needham LL, Burse VW, Head SL, et al. Adipose tissue/serum partioning of chlorinated hydrocarbon pestitissue/serum partioning of chlorinated hydroca
cides in humans. Chemosphere 1990;20:975-80.

24 Kemper FH. Human organ specimen banking - 15 years of experience. Sci Total Environ 1993;139-140:13-25.

25 Lommel A KH, Müller E. Organochlorine pesticides, octachlorostyrene, and mercury in the blood of Elb river residents, Germany. Arch Environ Contam Toxicol 1992;22: $14-20$.

26 Otero R, Grimalt JO. Organochlorine compounds in foodstuffs produced near a chlorinated organic solvent factory. Toxicological and Environmental Chemistry 1994;16:6172.

27 Ferrer A, Bona MA, Castellano M, et al. Organochlorine residues in human adipose tissue of the population of Zaragoza (Spain). Bull Environ Contam Toxicol 1992;48: 561-6.

28 Gomez-Catalan J, Planas J, To-Figueras J, et al. Organochlorine pesticide residues in the population of Catalonia (Spain). Bull Environ Contam Toxicol 1993;51:160-4.

29 To-Figueras J, Sala M, Otero R, et al. Metabolism of hexachlorobenzene in humans: association between serum 
levels and urinary metabolites in a highly exposed population. Environ Health Perspect 1997;105:78-83

30 Mes J, Malcolm S. Comparison of chlorinated hydrocarbon residues in human population from the Great Lakes and other regions of Canada. Chemosphere 1992;25:417-24.

31 Kreiss K, Zack MM, Kimbrough R, et al. Cross-sectiona study of a community with exceptional exposure to DDT fAMA 1981;245:1926-30.

32 Rogan WJ, Gladen BC, McKinney JD, et al. Polychlorinated biphenyls (PCBs) and dichlorodiphenyl dichloroethene (DDE) in human milk: effects of maternal factors and previous lactation. Am f Public Health 1986;767:172-7.

33 Currier MF, Mcclimans CD, Barna-Lloyd G. Hexachlorobenzene blood levels and the health status of men employed in the manufacture of chlorinated solvents. $f$ Toxicol Environ Health 1980;6:367-77.
34 Yabg RSH, Pittman KA, Rourke DR, et al. Pharmacokinetics and metabolism of hexachlorobenzene in the rat and the thesus monkey. Fournal of Agricultural and Food Chemistry

35 Anderson HA. Utilization of adipose tissue biopsy in characterizing human halogenated hydrocarbon exposure. Environ Health Perspect 1985;60:127-31.

36 Sim MR, McNeil JJ. Monitoring chemical exposure using breast milk: a methodological review. Am f Epidemiol 1992; 136:1-11.

37 Burse VW, Groce DF, Caudill SP, et al. Determination of polychlorinated biphenyl levels in the serum of residents and in the homogenates of seafood from the New Bedford, Massachusetts, area: a comparison of exposure sources through pattern recognition techniques. Sci Total Environ 1994;144:153-77.

\section{Occupational and Environmental Medicine and the electronic age}

OEM has an Email address which is 100632.3615@compuserve.com. We welcome contact by Email, including letters to the editor. Many of our reviewers send us their reports by Email, helping to speed up the peer review process.

Our publishing system is now fully electronic, and authors are sending their revised copy to us on disk as well as paper. Watch for revised Instructions to Authors.

The Editor 